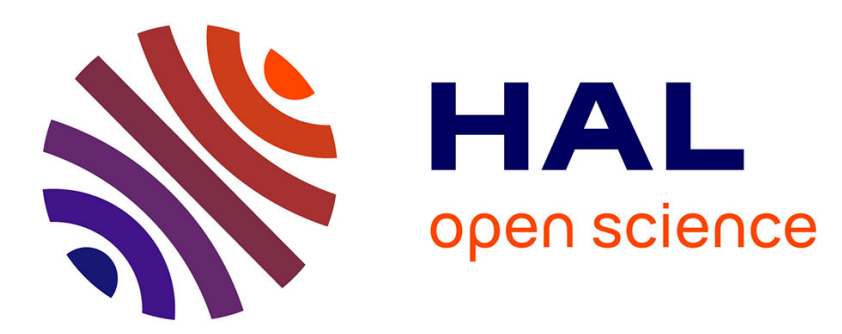

\title{
Would the (too?) normal adaptation to exercise in sickle cell trait carrier be a reflection of preventive mechanisms against potential myocardial and muscle injury?
}

Sophie Antoine-Jonville, K Reminy, Et N"go Sock, P Cherubin, O Hue, S Henri

\section{To cite this version:}

Sophie Antoine-Jonville, K Reminy, Et N"go Sock, P Cherubin, O Hue, et al.. Would the (too?) normal adaptation to exercise in sickle cell trait carrier be a reflection of preventive mechanisms against potential myocardial and muscle injury?. ESC Preventive Cardiology 2021, Apr 2021, Ljubljana, Slovenia. 28 (Supplement_1), 2021, 10.1093/eurjpc/zwab061.376 . hal-03339793

\section{HAL Id: hal-03339793 https://hal.science/hal-03339793}

Submitted on 9 Sep 2021

HAL is a multi-disciplinary open access archive for the deposit and dissemination of scientific research documents, whether they are published or not. The documents may come from teaching and research institutions in France or abroad, or from public or private research centers.
L'archive ouverte pluridisciplinaire HAL, est destinée au dépôt et à la diffusion de documents scientifiques de niveau recherche, publiés ou non, émanant des établissements d'enseignement et de recherche français ou étrangers, des laboratoires publics ou privés. 
Would the (too?) normal adaptation to exercise in sickle cell trait carriers be a reflection of preventive mechanisms

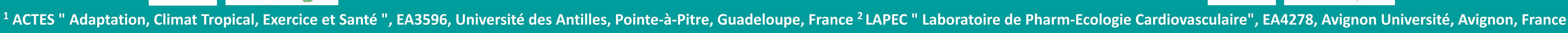

Sickle cell trait (SCT) is an inherited red blood cell condition without medical consequence in most cases. However, it is strongly associated with increased risk of exercise-induced sudden death, in particular in warm environment.

Fig 1 . Red blood cell sickling in SCT due to the hemoglobin.

Aims of the study: 1 ) compare the biomarkers of myocardial and muscle injury response to exercise in SCT and non-SCT; 2) identify the potential deleterious role of warmth during exercise

Methods 20 healthy young males with and without SCT, comparable in BMI, physical fitness, physical activity participated in the randomized controlled trial.

TO

T50

T110

T180

warm-up + incremental test

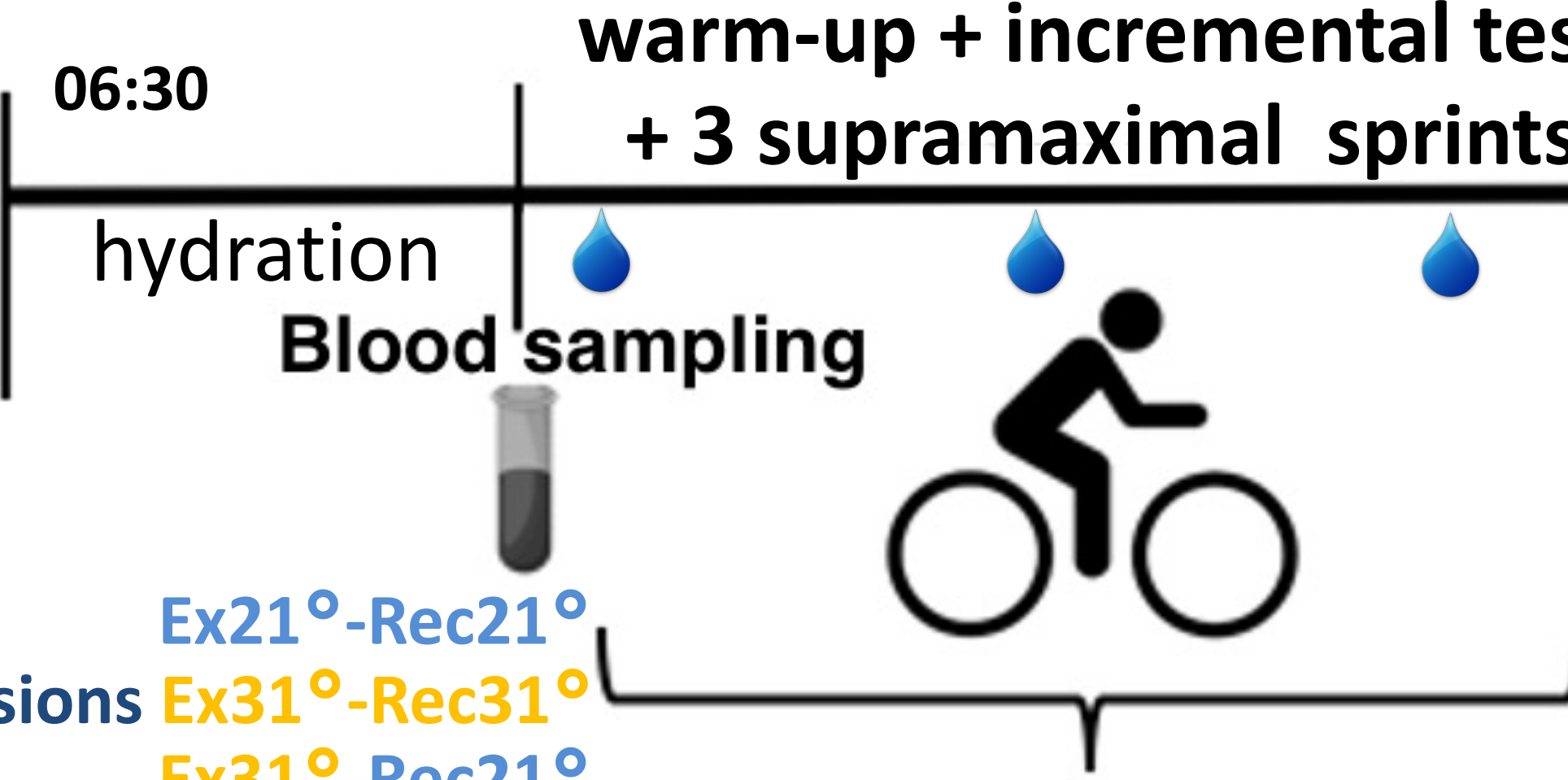

Strenuous exercise protocol at $21^{\circ} \mathrm{C}$ or $31^{\circ} \mathrm{C}$

\section{Results}

Clinical signs of occlusive events,

Rhabdomyolysis markers

- cardiac injury biomarker complete blood count

Performance and cardiorespiratory parameters

Lactate

Cortisol and glucose

\section{non-SCT}

None

Normal evolution with exercise

Normal adaptation to exercise and recovery

Normal adaptation to exercise and recovery Normal adaptation to exercise at $31^{\circ} \mathrm{C}$

Significantly LOWER values in SCT compared with non-SCT ( $p=0.043$ ). Lesser exercise-induced increase in SCT Trend $(p=0.062)$ for LOWER values in SCT during exercise; Significantly LOWER values in SCT during the recovery in particular after exercise at $31^{\circ} \mathrm{C}$

The exercise-induced increase in cortisol and glucose concentrations observed in non-SCT did not occur in SCT.

SCT

None

Normal evolution with exercise

Normal adaptation to exercise and recovery

Normal adaptation to exercise and recovery
Fig 1. Mean CORTISOL $(\mathrm{ng} / \mathrm{mL})$ throughout the sessions in SCT (full lines) and non-SCT (dotted lines). Exercise: time $\mathrm{x}$ group interaction effect: $\mathrm{p}=0.033$. Recovery: Group effect: $p=0.003$.

Conclusions

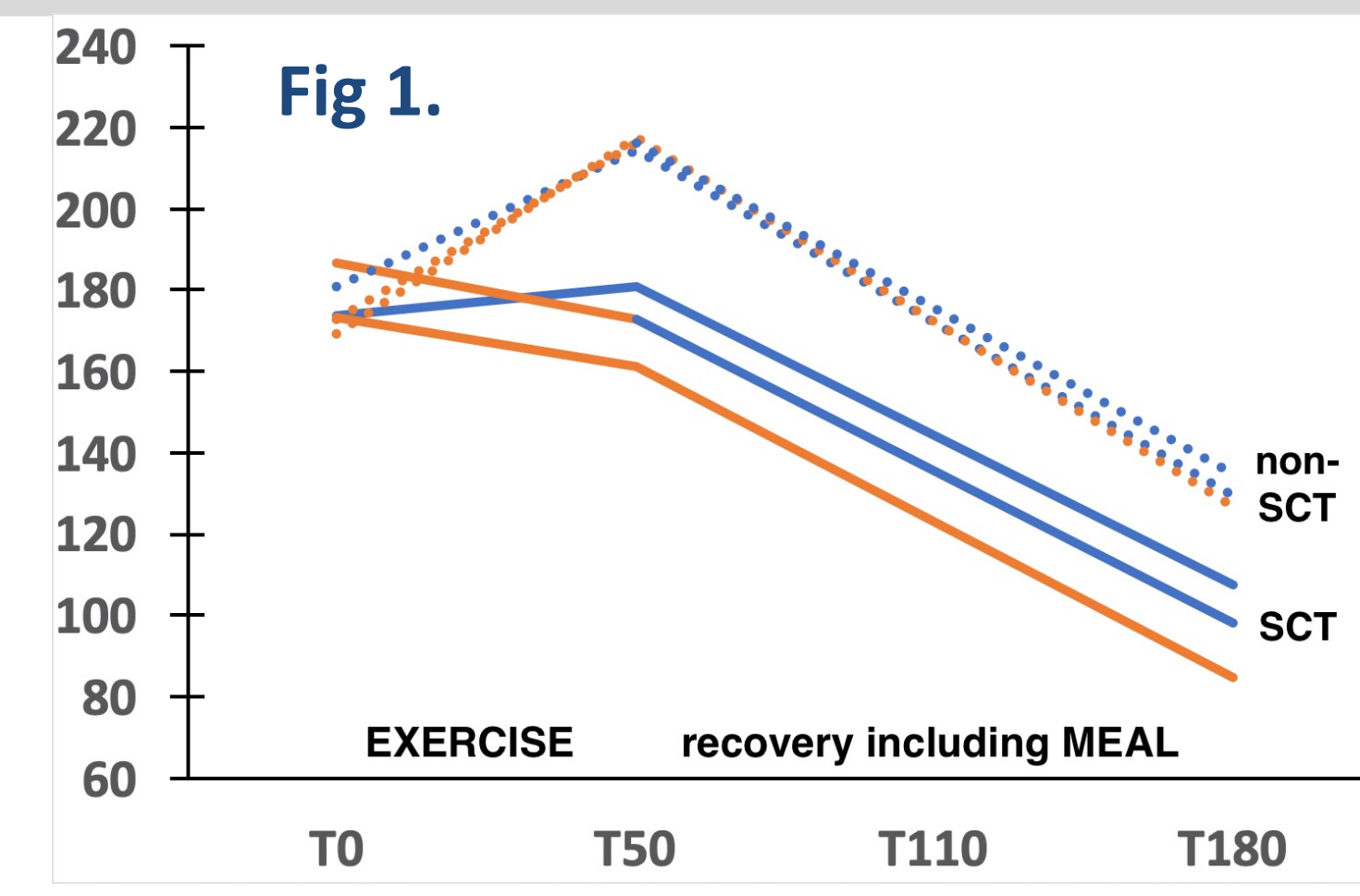
- This study extends the accepted knowledge on the parameters that present normal adaptation to exercise, whether the environmental temperature is control or warm.

- This environmental temperature during recovery does not influence the cardiovascular risk profile.

- The contribution of the absence of cortisol rise during exercise to this normal profile is highly questionable. This should be investigated as a track to explain the SCT carriers specific triggering of the metabolic and vascular crisis in fatal events. 